\title{
PENINGKATAN KUALITAS SPERMATOZOA PADA PROSES PEMISAHAN SPERMATOZOA DENGAN SENTRIFUGASI GRADIEN DENSITAS PERCOLL MELALUI PEMBERIAN FOSFOLIPID
}

\section{THE IMPROVEMENT OF SPERMATOZOA QUALITY IN THE SEPARATION OF SPERMATOZOA WITH PERCOLL GRADIENT DENSITY CENTRIFUGATION USING PHOSPHOLIPIDS}

\author{
Rooije R.H. Rumende*, Handono Kalim ${ }^{* *}$, M Aris Widodo**, Moch Sasmito Djati*** \\ *Program Doktor IImu Kedokteran, Minat Bio-Reproduksi, Pascasarjana Universitas Brawijaya Malang \\ ** Laboratorium IImu Penyakit Dalam Fakultas Kedokteran Universitas Brawijaya Malang \\ *** Laboratorium Farmakologi Fakultas Kedokteran Universitas Brawijaya Malang \\ **** Jurusan Biologi Fakultas Matematika dan IImu Pengetahuan Alam Universitas Brawijaya Malang
}

\begin{abstract}
The separation of $X$ and $Y$ spermatozoa can be conducted by using Percoll Gradient Density Centrifugation (SGDP) method. It is, easy, valid, cheap and applicable method for developing made-insemination. Although it has often been applied in sexing the spermatozoa, it was reported that the method had often caused damages on the spermatozoa membranes and resulted in decreasing of the spermatozoa quality. The damages of spermatozoa after SGDP process were specifically caused by (I) the loss of seminal plasma, (II) the increase of free radicals, and (III) the collision or friction among the spermatozoa. Among the three causal factors above, the third or the physical factor is claimed to be the most important one. It was assumed that the first and the second factors can be overcome if the third one is avoided. The spermatozoa membranes consist of lipids, protein, carbohydrate, and some substances at a low rate. The general objectives of this research was to identify the influence of the phospholipids PC (Phosphatidylcholin) to spermatozoa in order to avoid the damages of the spermatozoa in the process of SGDP. This research was conducted in Balai Besar Inseminasi Buatan (BBIB) Singosari Malang and at the Biology Laboratory of Mathematics and Science Faculty, UNIBRAW Malang. The cements used were from the bulls (Frishian Holstein) aged 5 to 8 years old bred in at BBIB above. The research method used was laboratory experimental study with the variables of motility of spermatozoa, viability of spermatozoa, membrane integrity spermatozoa, pre-capacitatated spermatozoa and post-capacitated spermatozoa, and acrosome reaction spermatozoa. The result showed that treating all spermatozoa with phospholipids $P C$ before SGDP process will improve the integrity of the spermatozoa membranes and keep the motility of spermatozoa, viability of spermatozoa, pre-capacitatated spermatozoa and post-capacitated spermatozoa, and spermatozoa of acrosome reaction. It was concluded that the concentration of phospholipids PC $10 \%$ is the best concentration in producing good spermatozoa in all variables.
\end{abstract}

Key words: SGDP, Phospholipids PC, Spermatozoa Quality

\section{PENDAHULUAN}

Tujuan dan manfaat pengaturan jenis kelamin adalah mendapatkan anak dengan jenis kelamin sesuai harapan, dan program pembibitan lebih cepat. Tujuan dan manfaat tersebut dapat dicapai dengan menggunakan metode sexing spermatozoa (pemisahan spermatozoa $X$ dan $Y$ ). Teknologi inseminasi buatan dapat ditingkatkan nilainya dengan menggunakan metode sexing melalui program breeding dalam pemilihan bibit unggul, sehingga zigot yang dihasilkan mempunyai jenis kelamin sesuai harapan (1).

Jurnal Kedokteran Brawijaya, Vol. XXIII, No. 2, Agustus 2007 Korespondensi: Rooije RH Rumende; Program Doktor, Minat Bio-Reproduksi, Pascasarjana Unibraw Malang; 081333111166
Pemisahan spermatozoa $X$ dan $Y$ dapat dilaksanakan dengan menggunakan metode sentrifugasi gradien densitas percoll (SGDP). Keuntungan penggunaan metode SGDP selain mudah dilaksanakan dan dapat diaplikasikan untuk keperluan pengembangan teknologi inseminasi buatan, juga merupakan metode yang valid dan menekan biaya (murah). Walaupun metode SGDP banyak digunakan untuk sexing spermatozoa, namun hasil-hasil penelitian terkini menunjukkan bahwa metode SGDP menyebabkan kerusakan membran spermatozoa yang berdampak pada penurunan kualitas spermatozoa.

Kerusakan membran spermatozoa setelah proses SGDP, disebabkan oleh tiga faktor, yakni: 1) hilangnya seminal plasma, 2) faktor kimia yang ditandai dengan peningkatan radikal bebas, dan 3) faktor fisik yang terjadi karena 
adanya gesekan/benturan sesama spermatozoa. Di antara ketiga faktor tersebut, faktor fisik adalah yang paling utama dengan asumsi bahwa apabila faktor fisik dapat diatasi, maka faktor kimia dan faktor hilangnya seminal plasma dapat dinetralisir. Selain itu yang paling berperan pada faktor fisik adalah keutuhan membran spermatozoa yang tersusun dari lipid, protein, karbohidrat, dan zat-zat lain yang kandungannya sedikit (2).

Penelitian pemisahan spermatozoa $X$ dan $Y$ pada sapi dengan metode SGDP, telah dilaksanakan oleh Susilawati (2000) (1). Hasil penelitian adalah, terjadi peningkatan ion kalsium dalam spermatozoa, sedangkan spermatozoa hasil SGDP mengalami kerusakan struktur membran pada bagian kepala maupun pada bagian ekor. Peningkatan kadar kalsium intraseluler pada spermatozoa, disebabkan oleh kerusakan struktur membran (setelah sentrifugasi) yang berpengaruh terhadap penurunan motilitas, penurunan viabilitas, penurunan integritas membran, sedangkan kapasitasi mengalami peningkatan. Tucker dan Jansen (2002) menyatakan bahwa separasi spermatozoa menggunakan metode SGDP dapat menyebabkan kerusakan spermatozoa (2). Peneliti lain berpendapat pemeriksaan Hypoosmotic swelling test (Hos test) terhadap spermatozoa hasil sentrifugasi menunjukkan adanya kerusakan tudung akrosom.

Uraian hasil-hasil penelitian di atas menyatakan bahwa, spermatozoa hasil proses SGDP mengalami penurunan kualitas spermatozoa. Kenyataan ini merupakan masalah selama ini dalam pengembangan pemisahan kromosom $X$ dan $Y$ pada spermatozoa dengan metode SGDP. Apabila dilihat dari struktur membran yang rusak, struktur membran terdiri dari lipid, protein, karbohidrat, dan zat-zat lain yang kandungannya sedikit. Untuk mengantisipasi kerusakan membran akibat proses SGDP, lipid memegang peran dalam menjaga kestabilan membran. Lipid, didalamnya terdapat fosfolipid, dimana fosfolipid merupakan bagian integral membran spermatozoa yang sangat berperan pada permeabilitas membran, reaksi enzim-enzim yang terdapat pada membran spermatozoa, dan perubahan spermatozoa pada traktus genitalia betina yaitu proses-proses kapasitasi dan proses fertilisasi (3). Fosfolipid merupakan komponen membran spermatozoa yang berfungsi sebagai stabilisator, penyerapan dan proses penyempurnaan fosfolipid terjadi selama proses maturasi di epididimis bersamaan dengan struktur membran dan penyempurnaan sifat permeabilitas membran (4).

Pemberian fosfolipid, akan memperbaiki struktur membran yang rusak. Hal ini berdasarkan pada hasil-hasil penelitian terdahulu menyatakan pemberian fosfolipid esensial akan memperbaiki metabolisme lipid (5). Pemberian fosfolipid esensial akan meningkatkan sintesis lipid membran pada retikulum endoplasmik $(6,7,8)$.
Tujuan penelitian ini adalah untuk mengungkap pengaruh pemberian fosfolipid PC (Phosphatidylcholin) pada kualitas spermatozoa setelah proses SGDP.

\section{METODE}

Penelitian ini dilaksanakan di Balai Besar Inseminasi Buatan (BBIB) Singosari Malang, Laboratorium Biomedik Fakultas Kedokteran UNIBRAW Malang, dan Laboratorium Biologi Fakultas Matematika dan IImu Pengetahuan Alam, Unibraw Malang. Sampel yang digunakan adalah semen yang berasal dari sapi pejantan Frishian Holstein $(\mathrm{FH})$ yang berada di Balai Besar Inseminasi Buatan (BBIB) Singosari Malang yang berumur 5-8 tahun. Penelitian ini merupakan penelitian experimental laboratorium dengan menggunakan fosfolipid PC (5\%,10\%, 20\%), yang diberikan sebelum proses SGDP. Setelah proses SGDP, dilanjutkan dengan pengamatan variabel-variabel yang terdiri dari motilitas spermatozoa, viabilitas spermatozoa, integritas membran spermatozoa, spermatozoa belum kapasitasi, spermatozoa yang mengalami kapasitasi dan spermatozoa yang mengalami reaksi akrosom. Analisis statistik menggunakan One way classification analyses of variance / ANOVA untuk melihat signifikansi kadar mana yang terbaik pada setiap variabel, dilanjutklan dengan uji BNT untuk melihat signifikansi antara spermatozoa tanpa perlakuan dan spermatozoa kontrol setelah proses SGDP. Uji jarak dengan uji berganda Duncan untuk melihat pengaruh masing-masing kadar pada setiap variabel (9). Analisa regresi linier untuk mengetahui pengaruh integritas membran pada setiap variabel pada perlakuan fosfolipid PC (9). Menggunakan metode indeks efektifitas De Garmo untuk mengetahui kadar mana yang terbaik di semua variabel pada perlakuan fosfolipid PC (10).

\section{Metode Sentrifugasi Gradien Densitas Percoll}

1. Pembuatan gradient densitas percoll. Gradien densitas yang digunakan adalah 1,$036 ; 1,038 ; 1,043 ; 1,047$; 1,$052 ; 1,055 ; 1,057 ; 1,0605 ; 1,065$ sampai 1,070 yang diperoleh dari pengenceran percoll dengan Tris aminomethan fosfolipid menjadi $20 \% ; 25 \% ; 30 \% ; 35 \% ; 40 \%$; $45 \% ; 50 \% ; 55 \% ; 60 \%$ dan $65 \%$. Kemudian larutan dari berbagai densitas tersebut disusun dalam tabung secara berurutan dari densitas tertinggi sampai terendah masing-masing $0,5 \mathrm{ml}$.

2. Pelaksanaan sentrifugasi. Satu $\mathrm{ml}$ semen yang telah memenuhi syarat dimasukkan tabung yang telah berisi gradient densitas percoll, kemudian disentrifugasi dengan kecepatan 2250 rpm (850 G) selama 5 menit. Hasil sentrifugasi menjadi 6 lapisan, pada lapisan teratas adalah seminal plasma dibuang dan pada lapisan kedua adalah yang banyak mengandung spermatozoa $Y$, sedangkan pada lapisan bawah yang banyak mengandung spermatozoa $X$ diambil dan dimasukkan dalam tabung yang telah berisi Tris aminomethan fosfolipid sebanyak $3 \mathrm{ml}$, kemudian 
disentrifugasi dengan kecepatan $1500 \mathrm{rpm}$ (380 G) selama 5 menit. Supernatan dibuang dan sisanya $1 \mathrm{ml}$ cairan yang banyak mengandung spermatozoa

Setelah perlakuan pada proses SGDP $( \pm 30$ menit proses SGDP). dilanjutkan proses pewarnaan $( \pm 15$ menit proses pewarnaan). Pengamatan kualitas spermatozoa dimulai pada menit $k e \pm 45$.

\section{Pengamatan motilitas spermatozoa (11)}

Sepuluh $\mu$ spermatozoa diteteskan pada objek gelas cekung; ditutup dengan cover gelas ukuran $22 \times 22 \mathrm{~mm}$ dan diamati dengan mikroskop cahaya dengan pembesaran 400x dan menggunakan computer assisted semen analysis (CASA). Paling sedikit 200 spermatozoa dihitung. Motilitas spermatozoa dibagi 4 kriteria; A. Pergerakan sangat baik, B. Pergerakan baik, C. Pergerakan tidak progesif, D. Tidak bergerak. Keempat kriteria tersebut, diamati dengan mikroskop cahaya dengan pembesaran 400x. Data yang diperoleh digunakan sebagai pembanding pada pengamatan motilitas spermatozoa dengan menggunakan CASA.

\section{Pengamatan viabilitas Spermatozoa (11)}

Semen ditetesi 1 tetes larutan Eosin-Negrosin diletakkan pada object glass, dihomogenkan dan dibuat hapusan, kemudian dikeringkan. Pengamatan dilakukan dengan mikroskop cahaya dengan pembesaran 400x. Spermatozoa yang hidup tidak menyerap warna, sedangkan yang mati akan menyerap warna, dihitung sebanyak 200 spermatozoa.

\section{Pengamatan kapasitasi}

Metode yang digunakan adalah seperti diuraikan oleh Fraser (1995) dan telah dimodifikasi oleh Djati (2005) sebagai berikut: seratus $\mu$ semen dimasukkan dalam ependrof kapasitas $1,5 \mathrm{ml}$ yang ditutup dengan aluminium foil, tambahkan $45 \mu$ larutan pewarna CTC dan divortex selama 1 menit, tambahkan $8 \mu \mathrm{l}$ CTC Fixative dan divortex selama 1 menit, larutan tersebut diambil $10 \mu \mathrm{DABCO}$ dan dicampur secara hati-hati, kemudian ditutup dengan cover glass, selanjutnya ditutup dengan kertas tisu yang tebal dan ditekan secara hati-hati, tepi cover glass ditutup dengan kutex untuk melindungi dari kekeringan (12). Pengamatan dilakukan dengan mikroskop epifluorescence (Nikon) dengan pembesaran 400x. Penampakan adalah keseluruhan kepala spermatozoa berwarna terang adalah belum kapasistasi, setengah bagian atas kepala spermatozoa berwarna terang adalah spermatozoa kapasitasi, kepala yang hanya bagian tengahnya saja berwarna terang atau timbul cincin yang melingkar di tengah kepala spermatozoa adalah spermatozoa yang telah mengalami reaksi akrosom.

\section{Pengamatan integritas membran dengan Hypoosmotic Swelling Test $(1,13)$}

Satu $\mathrm{ml}$ larutan hipoosmotik $150 \mathrm{~m}$ osmol ditambah $0,1 \mathrm{ml}$ spermatozoa. Inkubasi pada suhu $37^{\circ} \mathrm{C}$ selama 30 menit. Amati dengan pembesaran 400x terdapat perubahan khas pada kerusakan membran yaitu dengan adanya pembengkakan spermatozoa atau bagian ujung ekor yang melingkar.

\section{HASIL PENELITIAN}

\section{Kualitas Spermatozoa Sapi yang Akan Diteliti}

Semen segar diperoleh dari sapi pejantan Frishian Holstein (FH) yang berada di Balai Besar Inseminasi Buatan (BBIB) Singosari Malang yang berumur 5-8 tahun. Evaluasi terhadap semen segar secara makroskopik maupun mikroskopik dilakukan segera setelah proses penampungan semen. Pemeriksaan makroskopik meliputi volume dan $\mathrm{pH}$, sedangkan pemeriksaan mikroskopik meliputi konsentrasi, motilitas, viabilitas, integritas membran, spermatozoa yang belum mengalami kapasitasi, spermatozoa yang mengalami kapasitasi dan spermatozoa yang telah mengalami reaksi akrosom. Hasil pemeriksaan semen segar secara singkat ditunjukkan pada Tabel 1.

Tabel 1. Kualitas Spermatozoa Sapi yang Akan Diteliti

\begin{tabular}{ll}
\hline \multicolumn{1}{c}{ Parameter } & Rata-Rata \pm SD \\
\hline Volume (ml) & $9,09 \pm 1,01$ \\
$\mathrm{pH}$ & $6,31 \pm 0,09$ \\
Konsentrasi $\left(10^{6}\right)$ & $15115,5 \pm 214,85$ \\
Motilitas (\%) & $75,00 \pm 0,00$ \\
Viabilitas (\%) & $92,27 \pm 2,81$ \\
Integritas membran (\%) & $71,74 \pm 5,19$ \\
Spermatozoa belum kapasitasi (\%) & $55,16 \pm 6,14$ \\
Spermatozoa kapasitasi (\%) & $26,59 \pm 5,48$ \\
Spermatozoa reaksi akrosom (\%) & $18,12 \pm 2,36$ \\
\hline
\end{tabular}

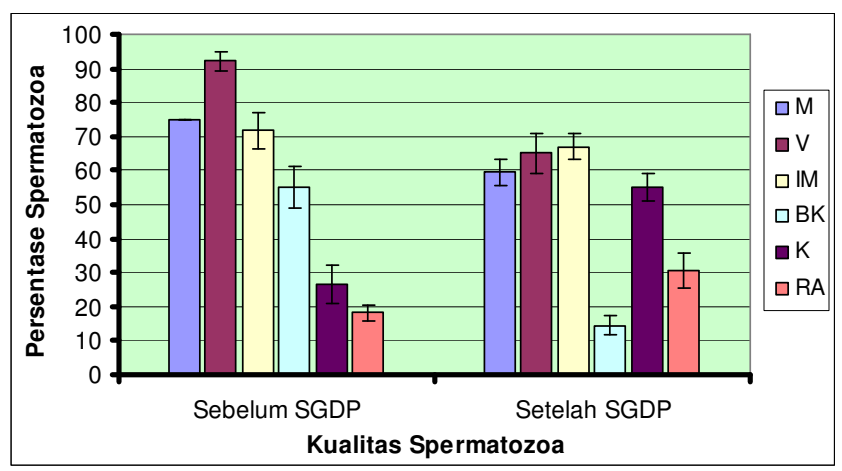

Gambar 1. Presentase \pm SD semua variabel sebelum perlakuan SGDP dan setelah perlakuan SGDP. Hasil uji BNT, $P<0,01$.

Keterangan spermatozoa:

Motilitas (M), Viabilitas (V), Integritas

Membran (IM), Belum kapasitasi (BK),

Kapasitasi (K), Reaksi akrosom (AK). 
Pengaruh Sentrifugasi Gradien Densitas Percoll pada Kualitas Spermatozoa Sapi

Hasil penelitian sekaligus analisis statistik (Gambar 1) menunjukkan bahwa persentase kualitas spermatozoa pada semua variabel (motilitas spermatozoa, viabilitas spermatozoa, integritas membran spermatozoa, spermatozoa belum kapasitasi, spermatozoa yang mengalami kapasitasi, spermatozoa yang mengalami reaksi akrosom) setelah perlakuan SGDP menurun secara sangat nyata (Uji BNT P< 0,001 ) dibandingkan dengan kontrol/tanpa SGDP. Artinya, proses SGDP memberikan pengaruh yang sangat nyata pada penurunan kualitas spermatozoa pada semua variabel.

\section{Pengaruh Fosfolipid PC pada Spermatozoa Sapi setelah SGDP}

Hasil penelitian sekaligus analisis statistik pada pemberian fosfolipid PC $(5 \%, 10 \%, 20 \%)$ pada spermatozoa yang dilanjutkan dengan proses SGDP, menunjukkan bahwa persentase kualitas spermatozoa pada semua variabel (motilitas spermatozoa (Gambar 2), viabilitas spermatozoa (Gambar 3), integritas membran spermatozoa (Gambar 4), spermatozoa belum kapasitasi (Gambar 5), spermatozoa yang mengalami kapasitasi (Gambar 6), spermatozoa yang mengalami reaksi akrosom (Gambar 7)) meningkat secara sangat nyata (Hasil Anova $\mathrm{P}<0,001$ ) dibandingkan dengan kontrol pada SGDP. Artinya pemberian fosfolipid PC (5\%, $10 \%, 20 \%$ ) pada spermatozoa yang dilanjutkan dengan proses SGDP memberikan pengaruh sangat nyata pada kualitas spermatozoa pada semua variabel.

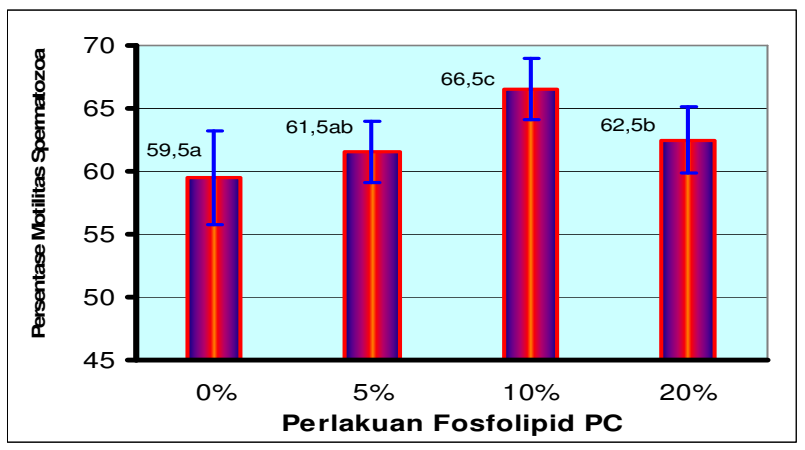

Gambar 2.Presentase \pm SD motilitas spermatozoa setelah perlakuan fosfolipid PC dilanjutkan dengan SGDP. Hasil Anova, $P<0,01$.

Keterangan: a, b, ab, c, (Hasil uji jarak berganda Duncan 5\%)

Uji lanjutan (uji Duncan) untuk mengetahui perbedaan rata-rata masing-masing perlakuan khusus untuk variabel motilitas (Gambar 2) menunjukkan bahwa konsentrasi fosfolipid PC 10\% (notasi c) menghasilkan rata-rata motilitas spermatozoa tertinggi, dan pada perlakuan fosfolipid PC $20 \%$ motilitas spermatozoa menurun (notasi b). Artinya ada keyakinan yang tinggi bahwa motilitas dengan perlakuan fosfolipid PC 10\% akan lebih baik dari perlakuan fosfolipid $20 \%$ atau perlakuan fosfolipid PC $5 \%$. Pada pem- berian fosfolipid PC 20\%, persentase motilitas spermatozoa telah menurun, hal ini di duga karena globula lemak pada fosfolipid PC yang berlebihan akan menghambat pergerakan spermatozoa menjadi terhambat. Keadaan ini sesuai dengan pendapat Hirai et al., (1997) dan Djauhari, (2005) yang menyatakan bahwa konsentrasi kuning telur yang semakin tinggi dalam pengencer tris pada semen sapi meningkatkan persentase spermatozoa yang motil (14).

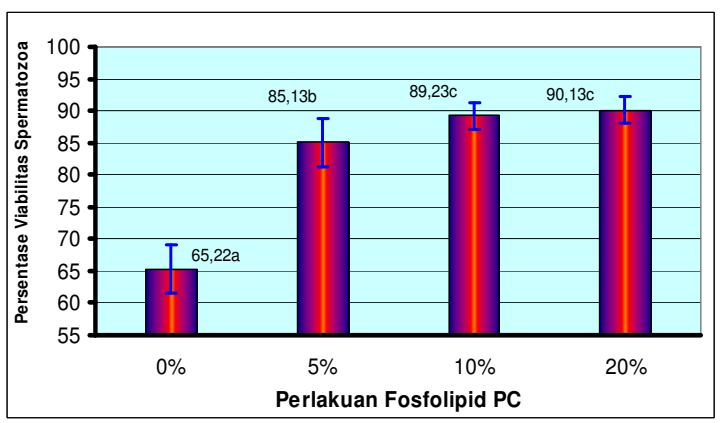

Gambar 3. Presentase \pm SD viabilitas spermatozoa setelah perlakuan fosfolipid PC dilanjutkan dengan SGDP. Hasil uji Anova, $P<0,01$.

Keterangan: a, b, c, (Hasil uji jarak berganda Duncan $5 \%$ )

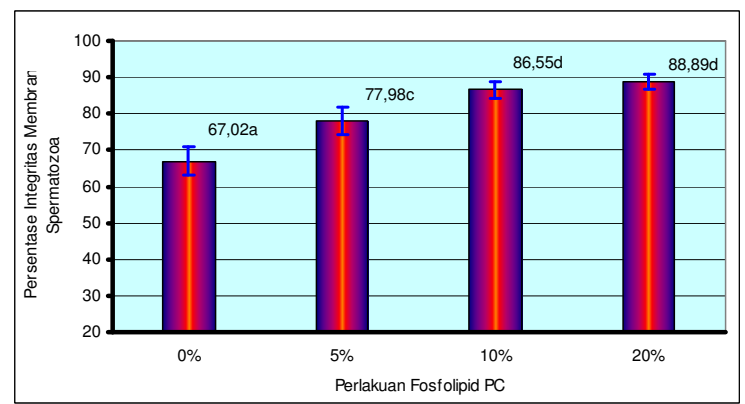

Gambar 4.Presentase \pm SD integritas membran spermatozoa setelah perlakuan fosfolipid PC dilanjutkan dengan SGDP. Hasil uji Anova, $\mathrm{P}<0,01$

Keterangan: a, c , d (Hasil uji jarak berganda Duncan 5\%)

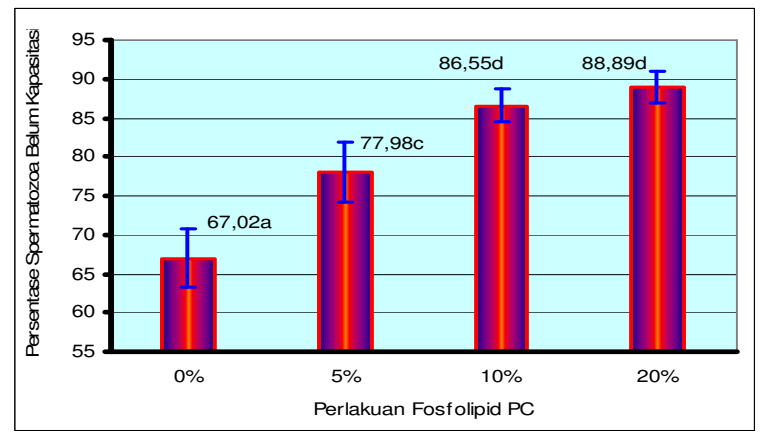

Gambar 5. Presentase \pm SD spermatozoa belum kapasitasi setelah perlakuan fosfolipid PC dilanjutkan dengan SGDP. Hasil uji Anova, $\mathrm{P}<0,01$

Keterangan: a, c, d (Hasil uji jarak berganda Duncan 5\%) 


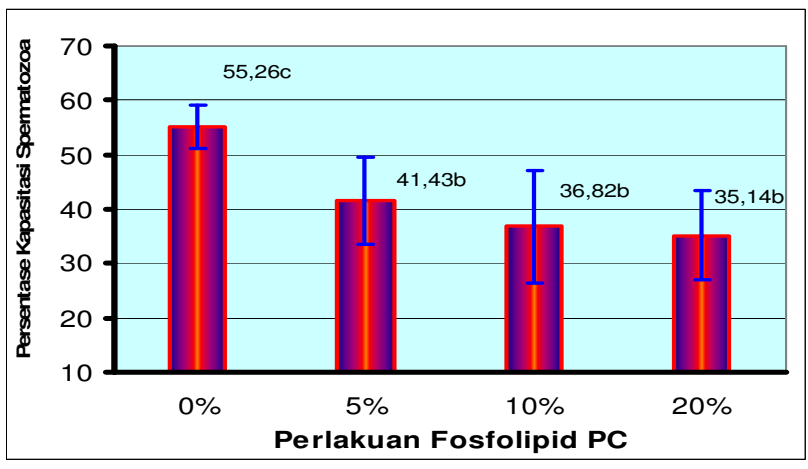

Gambar 6.Presentase \pm SD spermatozoa yang mengalami kapasitasi setelah perlakuan fosfolipid PC dilanjutkan dengan SGDP. Hasil uji Anova, $P<0,01$.

Keterangan: a, b, c (Hasil uji jarak berganda Duncan 5\%)

Uji lanjutan (uji Duncan) untuk mengetahui perbedaan rata-rata masing-masing perlakuan pada semua variabel selain variabel motilitas menunjukkan (Gambar 2,3,6,7, dan 8) bahwa konsentrasi fosfolipid PC 10 (notasi c untuk viabilitas spermatozoa, integritas spermatozoa; notasi $d$ untuk spermatozoa belum kapasitasi; notasi b untuk spermatozoa yang mengalami kapasitasi; notasi ab untuk spermatozoa yang mengalami reaksi akrosom) menghasilkan rata-rata spermatozoa tertinggi meskipun tidak berbeda nyata dengan konsentrasi fosfolipid PC $20 \%$ (notasi c untuk viabilitas spermatozoa, integritas spermatozoa; notasi $d$ untuk spermatozoa belum kapasitasi; notasi $b$ untuk spermatozoa yang mengalami kapasitasi; notasi ab untuk spermatozoa yang mengalami reaksi akrosom). Artinya belum ada keyakinan yang tinggi bahwa kualitas spermatozoa dengan perlakuan fosfolipid PC 10\% akan selalu lebih baik dari perlakuan fosfolipid PC $20 \%$.

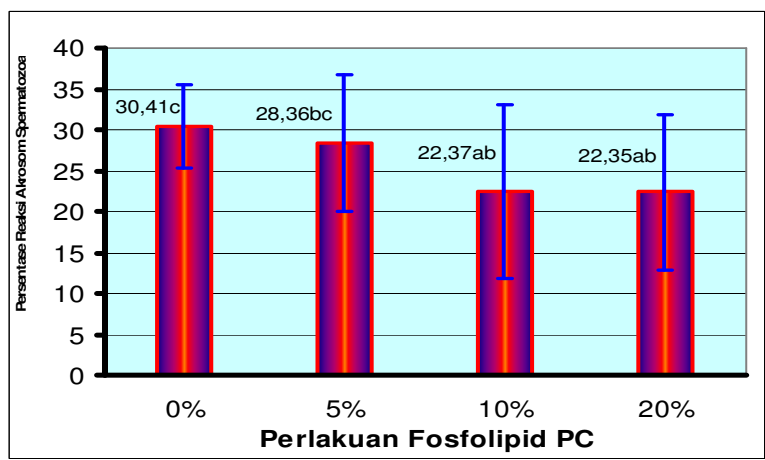

Gambar 7.Presentase \pm SD spermatozoa yang mengalami reaksi akrosom setelah perlakuan fosfolipid PC dilanjutkan dengan SGDP. Hasil uji Anova, $P<0,01$.

Keterangan: ab, bc, $c$ (Hasil uji jarak berganda Duncan 5\%)
Pemeriksaan viabilitas dilakukan dengan menggunakan metode eosin negrosin. Hasil pengamatan memperlihatkan bahwa spermatozoa yang mati menyerap warna (B) dan yang hidup tidak menyerap warna (B). Hal ini disebabkan karena spermatozoa mati tidak mempunyai integritas membran yang baik sehingga eosin negrosin akan mudah masuk ke dalam sel spermatozoa (Gambar 8).

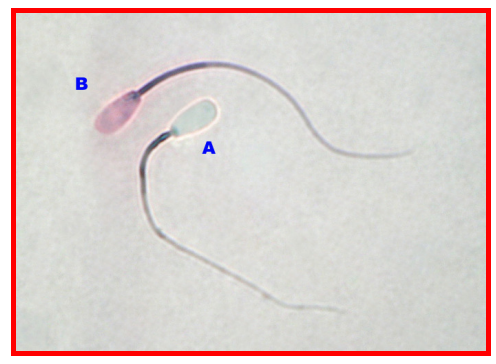

Gambar 8. Hasil pengamatan viabilitas spermatozoa dengan eosin negrosin pembesaran $1000 \mathrm{X}$ menggunakan mikroskop cahaya (OLYMPUS).

Keterangan: (A) Spermatozoa hidup (tidak menyerap warna)

(B) Spermatozoa mati (menyerap warna)

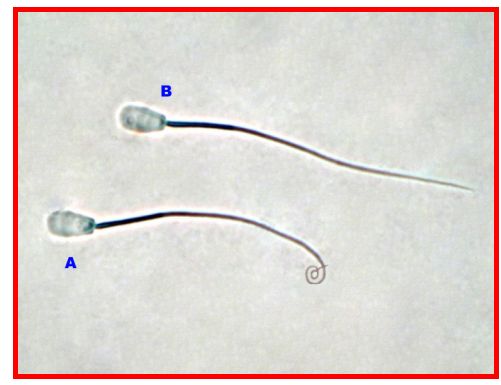

Gambar 9. Hasil pengamatan Integritas membran spermatozoa dengan pembesaran $1000 \mathrm{X}$ menggunakan mikroskop cahaya (OLYMPUS).

Keterangan: (A) Spermatozoa yang menggulung merupakan integritas membran spermatozoa yang utuh

(B) Spermatozoa yang tidak menggulung merupakan integritas membran spermatozoa yang rusak

Pemeriksaan integritas membran (Gambar 9) dilakukan dengan menggunakan metode Hypoosmotic Swelling Test (HOS test). Metode HOS test berfungsi untuk menguji utuh tidaknya membran yang masih berfungsi dengan aktif. Larutan hipoosmotik menyebabkan terjadinya transport air masuk ke dalam membran spermatozoa, sedangkan spermatozoa yang mempunyai membran yang rusak atau tidak aktif, tidak dapat menyesuaikan tekanan osmosenya. Masuknya cairan tersebut akan mengakibatkan membengkaknya sel dan ditandai dengan adanya ekor yang meng- 
gulung (Gambar A) (13). Spermatozoa yang menggulung merupakan integritas membran yang utuh (A). Spermatozoa yang tidak menggulung merupakan integritas membran yang rusak (B). Integritas membran spermatozoa yang rusak menyebabkan membran tidak semipermiabel teradap larutan hipoosmotik (Gambar B), nampak tidak melingkar ekornya.

Pemeriksaan spermatozoa belum kapasitasi, kapasitasi, dan reaksi akrosom, dapat dilihat dengan pewarnaan Chlortetracycline (CTC). Seorang peneliti mengatakan untuk melihat pendaran kalsium pada kepala spermatozoa digunakan pewarnaan CTC. Pendaran kalsium pada kepala spermatozoa dapat dilihat pada Gambar 10. Telah dijelaskan bahwa pewarnaan CTC pada spermatozoa dapat memperlihatkan tiga bentuk pendaran yaitu 1). distribusi kalsium yang merata pada kepala spermatozoa atau kepala spermatozoa berwarna terang (Gambar 10A), 2). Distribusi kalsium terkosentrasi pada daerah post acrosomal atau setengah bagian atas kepala spermatozoa berwarna terang (Gambar 10B), dan 3.distribusi kalsium pada daerah pangkal akrosom (Gambar $10 \mathrm{C}$ ) atau adanya cincin yang berwarna terang melingkar pada bagian tengah kepala spermatozoa.

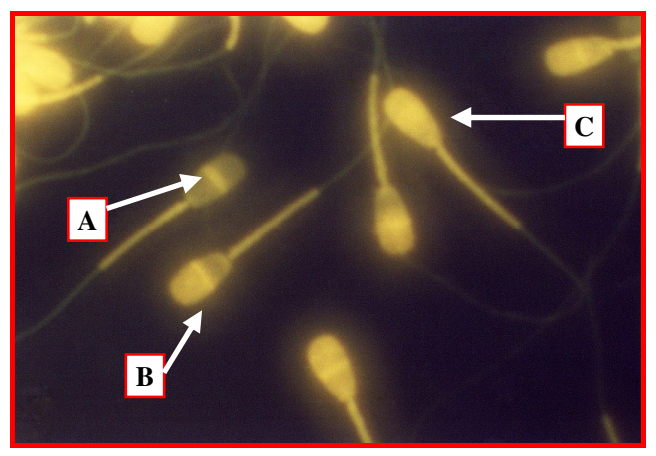

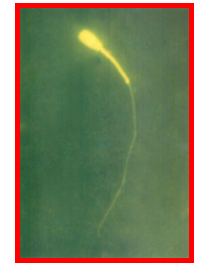

A

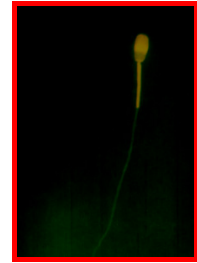

B

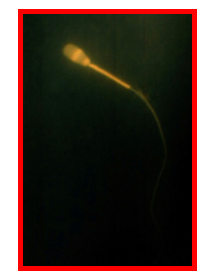

C
Gambar 10. Hasil pengamatan kondisi fisiologis spermatozoa setelah pewarnaan CTC dengan mikroskop epifluorescence (NIKON) perbesaran 400X.

Keterangan: A. Spermatozoa belum mengalami kapasitasi

B. Spermatozoa kapasitasi

C. Spermatozoa telah mengalami reaksi akrosom

\section{Metode Indeks Efektifitas De Garmo}

Secara keseluruhan variabel, hasil perlakuan yang terbaik dapat diketahui dengan menggunakan metode analisis Indeks Efektifitas De Garmo yang di tunjukkan pada Gambar 11.

Hasil perhitungan di atas menunjukkan bahwa perlakuan terbaik terjadi pada pemberian fosfolipid PC terbaik $10 \%$, diikuti fosfolipid terbaik $20 \%$, dan fosfolipid PC terbaik 5\%. Pemberian fosfolipid PC 10\% pada spermatozoa yang dilanjutkan dengan SGDP, merupakan perlakuan yang terbaik/optimal.

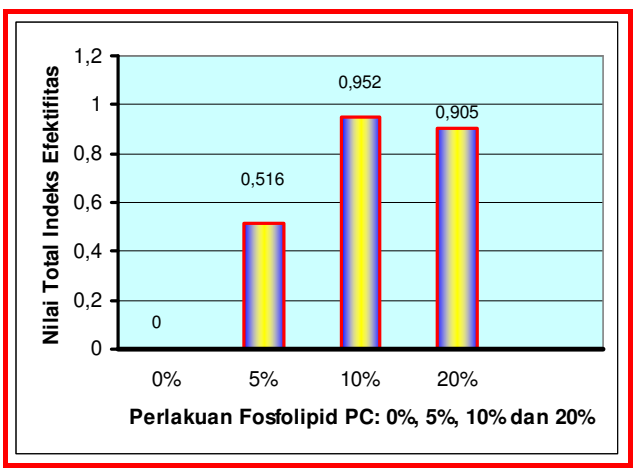

\section{Gambar 11. Nilai total Indeks Efektifitas pada erlakuan} fosfolipid PC.

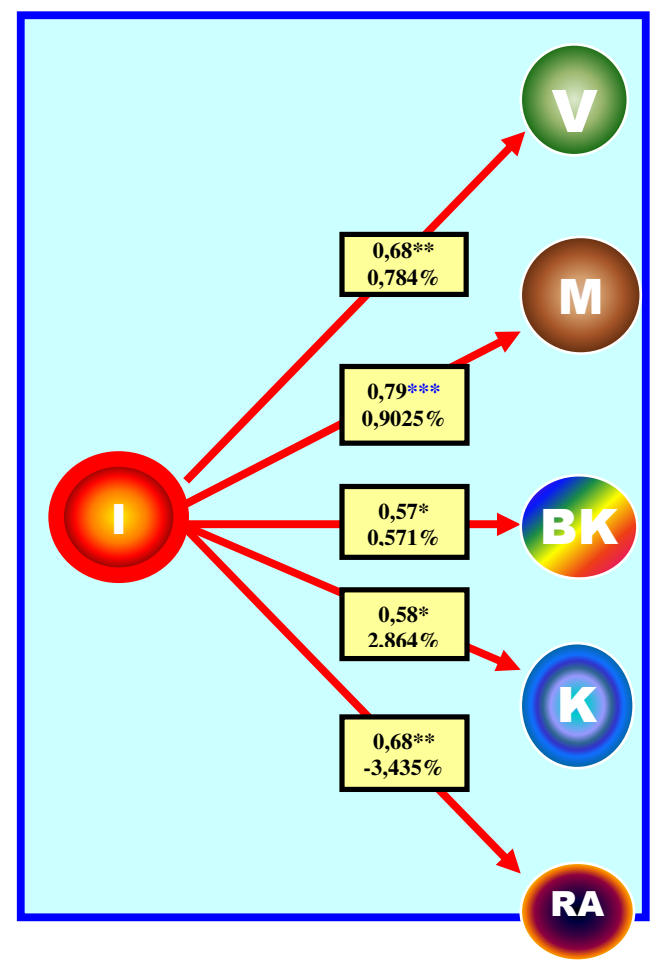

Keterangan:M=Motilitas, $\quad V=V$ iabilitas, $I M=$ Integritas membran, BK=Belum Kapasitasi, K=Kapasitasi, RA=Reaksi Akrosom. $\quad{ }^{*}=$ Tidak nyata, ${ }^{* *}=$ Nyata, $\quad{ }^{* * *}=$ Sangat nyata.

Gambar 12. Pengaruh efektifitas integritas membran terhadap masing-masing variabel pada perlakuan fosfolipid PC 10\% (Hasil analisis regresi linier) 


\section{Pengaruh Integritas Membran Spermatozoa terhadap Variabel-Variabel yang lain}

Pengaruh integritas membran spermatozoa terhadap variabel-variabel lain pada pemberian fosfolipid 10\%, secara umum dapat dilihat pada Gambar 12. Gambar 12 menunjukkan integritas membran spermatozoa memberikan pengaruh atau efek tertinggi 0,79 (pengaruh sangat kuat) pada motilitas spermatozoa, hasil uji model menyatakan pengaruhnya sangat nyata $(P<0,01)$, dan jika integritas membran naik $1 \%$ akan menaikkan motilitas spermatozoa sebesar $0,9025 \%$. Pengaruh atau efek selanjutnya secara berurutan adalah viabilitas spermatozoa, spermatozoa yang mengalami reaksi akrosom, dan Spermatozoa yang mengalami kapasitasi, spermatozoa yang belum mengalami kapasitasi.

\section{DISKUSI}

\section{Kualitas Spermatozoa Sapi yang Akan Diteliti}

Berdasarkan hasil pemeriksaan kualitas spermatozoa sapi yang akan diteliti (Tabel 1), umumnya data menunjukkan dalam keadaan normal (Volume perejakulasi berkisar 5-8 ml, Konsentrasi antara 700-2000 juta permililiter $(15,16)$. Semen yang mempunyai persentase motilitas di atas $70 \%$ lebih tahan hidup dibandingkan bila lebih rendah dari 70\%, Motilitas minimal $70 \%$ (Zenichiro dkk., 2002), Motilitas $>70 \%$, dan pH 5,9 - 7,3; Viabilitas $>80 \%$; Integritas membran $72,90 \%(11,17,18,19)$. Sehingga spermatozoa tersebut dapat dilanjutkan pada penelitian dengan pemberian perlakuan. Apabila terjadi perubahan kualitas spermatozoa setelah perlakuan, hal ini disebabkan oleh perlakuan pada pelaksanaan penelitian.

\section{Penurunan Kualitas Spermatozoa Setelah Sentrifugasi Gradien Densitas Percoll}

Hasil penelitian sekaligus analisis statistik (Gambar 1) menunjukkan bahwa persentase kualitas spermatozoa pada semua variabel setelah perlakuan SGDP menurun secara sangat nyata (Uji BNT $P<0,001$ ). Artinya, proses SGDP memberikan pengaruh yang sangat nyata pada penurunan kualitas spermatozoa pada semua variabel.

Hasil penelitian ini sejalan dengan hasil penelitian Susilawati dkk., (1999) yang menemukan adanya peningkatan kapasitasi spermatozoa sapi setelah pemisahan dengan SGDP (20). Peneliti lain mengatakan pemisahan spermatozoa dengan sentrifugasi dapat menginduksi terjadinya spermatozoa mengalami kapasitasi dan spermatozoa mengalami reaksi akrosom.

Menurunnya persentase kualitas spermatozoa pada semua variabel setelah perlakuan SGDP ini sangat wajar terjadi, karena spermatozoa telah mengalami serangkaian perlakuan mulai dari proses pemisahan hingga proses pencucian yang membutuhkan banyak energi untuk tetap menormalkan kondisi fisiologisnya. Hilangnya seminal plas- ma dari spermatozoa setelah proses SGDP dan menggantikan dengan medium Tris aminomethan, mungkin merupakan salah satu faktor yang menyebabkan menurunnya kualitas spermatozoa pada semua variabel, bila dihubungkan dengan ketersediaan sumber energi bagi spermatozoa. Seminal plasma selain merupakan medium transport bagi spermatozoa juga mengandung komponen-komponen elektrolit yang dapat menstimulir metabolisme untuk menghasilkan sejumlah energi berupa ATP yang penting untuk motilitas spermatozoa (21). Hal ini sesuai dengan pernyataan Hafez (2000) bahwa motilitas spermatozoa akan menurun jika plasma seminalis diganti dengan medium lain (11).

Seminal plasma selain diketahui banyak mengandung bahan-bahan nutrisi bagi spermatozoa juga mengandung bahan elektrolit dan non elektrolit seperti ion natrium, kalium, protein dan asam askorbat yang penting untuk melindungi spermatozoa dari kerusakan. Ion natrium dan kalium yang terdapat dalam seminal plasma berperan penting dalam menjaga entegritas fungsional membran plasma spermatozoa, protein berperan penting dalam melindungi membran plasma tetap lentur dan merupakan jaket bagi spermatozoa dari kerusakan irrevelsibel, sedangkan asam askorbat berperan sebagai zat antioksidan yang penting untuk melindungi spermatozoa dari serangan senyawa oksigen reaktif $(22,23)$.

Dengan demikian, hilangnya seminal plasma dari spermatozoa selama proses SGDP akan mengakibatkan perlindungan spermatozoa dari bahan-bahan perusak seperti serangan oksigen reaktif akan menjadi berkurang, sehingga spermatozoa mudah mengalami peroksidasi. Hal ini sesuai dengan laporan beberapa peneliti sebelumnya yang menyatakan bahwa tingginya kandungan asam askorbat dalam seminal plasma berregresi positif dengan keutuhan integritas membran plasma spermatozoa setelah pembekuan (22). Disebutkan oleh Susilowati dkk., (1997) bahwa separasi menggunakan gradien densitas percoll menyebabkan penurunan motilitas progresif sekitar $10 \%$ (20). Sebagaimana diketahui, seminal plasma berfungsi untuk melindungi spermatozoa dari pengaruh luar yang merupakan medium hidup, menurut pendapat Yanagimachi (1988), Buhr (1998) dan Hafez (1993) bahwa pada saat spermatoza masuk ke dalam seminal plasma, maka membran spermatozoa lebih stabil, jadi dengan terpisahnya spermatozoa dengan seminal plasma, maka membran spermatozoa menjadi tidak stabil $(21,24,25)$.

Faktor lain yang menyebabkan penurunan kualitas spermatozoa setelah proses SGDP diduga terjadi akibat pengaruh kimiawi dan mekanik langsung (fisik) gaya sentrifugasi seperti gesekan permukaan membran dengan partikel percoll atau dinding tabung. Beberapa peneliti melaporkan adanya gesekan/benturan mekanik yang terjadi antara permukaan spermatozoa dengan partikel percoll maupun dinding tabung selama proses SGDP dapat menyebabkan 
deformasi matriks ekstraseluler termasuk perubahan komposisi lipid membran yang penting dalam mempertahankan fluiditas membran spermatozoa $(26,27)$. Makin lama gesekan mekanik yang terjadi pada membran spermatozoa pada proses SGDP, maka makin besar pula kerusakan integritas membran plasma yang terjadi pada spermatozoa. Makin tinggi tingkat kerusakan membran plasma spermatozoa akan menyebabkan persentase spermatozoa yang memiliki membran plasma utuh makin menjadi menurun (26). Kolesterol dan fosfolipid merupakan komponen lipid membran spermatozoa yang sangat penting dalam mempertahankan integritas membran, namun sangat sensitif terhadap faktor-faktor ekstrinsik seperti suhu, dan polaritas pelarut.

Penurunan kualitas spermatozoa untuk keenam variabel sebagaimana yang telah dijelaskan di atas, disebabkan karena, spermatozoa hasil SGDP mengalami kerusakan struktur membran spermatozoa pada bagian kepala maupun bagian ekor Tucker dan Jansen (2002) menyatakan bahwa separasi spermatozoa menggunakan metode SGDP dapat menyebabkan kerusakan spermatozoa (2). Peneliti lain berpendapat pemeriksaan Hypoosmotic swelling test
(Hos test) terhadap spermatozoa hasil sentrifugasi menunjukkan adanya kerusakan tudung akrosom.

\section{Peningkatan Kualitas Spermatozoa Sapi pada Proses SGDP Melalui Pemberian Fosfolipid PC}

Hasil penelitian ini menunjukkan peningkatan kualitas spermatozoa setelah proses SGDP. Hasil Anova $(P<0,01)$, artinya pemberian fosfolipid PC pada spermatozoa yang dilanjutkan dengan proses SGDP, memberikan pengaruh sangat nyata dalam peningkatan kualitas spermatozoa.

Hammadeh et al., (2001) menyatakan bahwa penggunaan kuning telur dapat melindungi akrosom spermatozoa (26). Hirai et al., (1997) konsentrasi kuning telur dalam pengencer tris pada semen sapi meningkatkan persentase yang motil (14).

Penelitian lainnya juga melaporkan bahwa pemberian fosfolipid esensial akan memperbaiki metabolisme lipid (5). Pemberian fosfolipid esensial akan meningkatkan sintesis lipid membran pada retikulum endoplasmik $(6,7,8)$. Fosfolipid fungsinya adalah meningkatkan sintesis membran lipid spermatozoa (6).

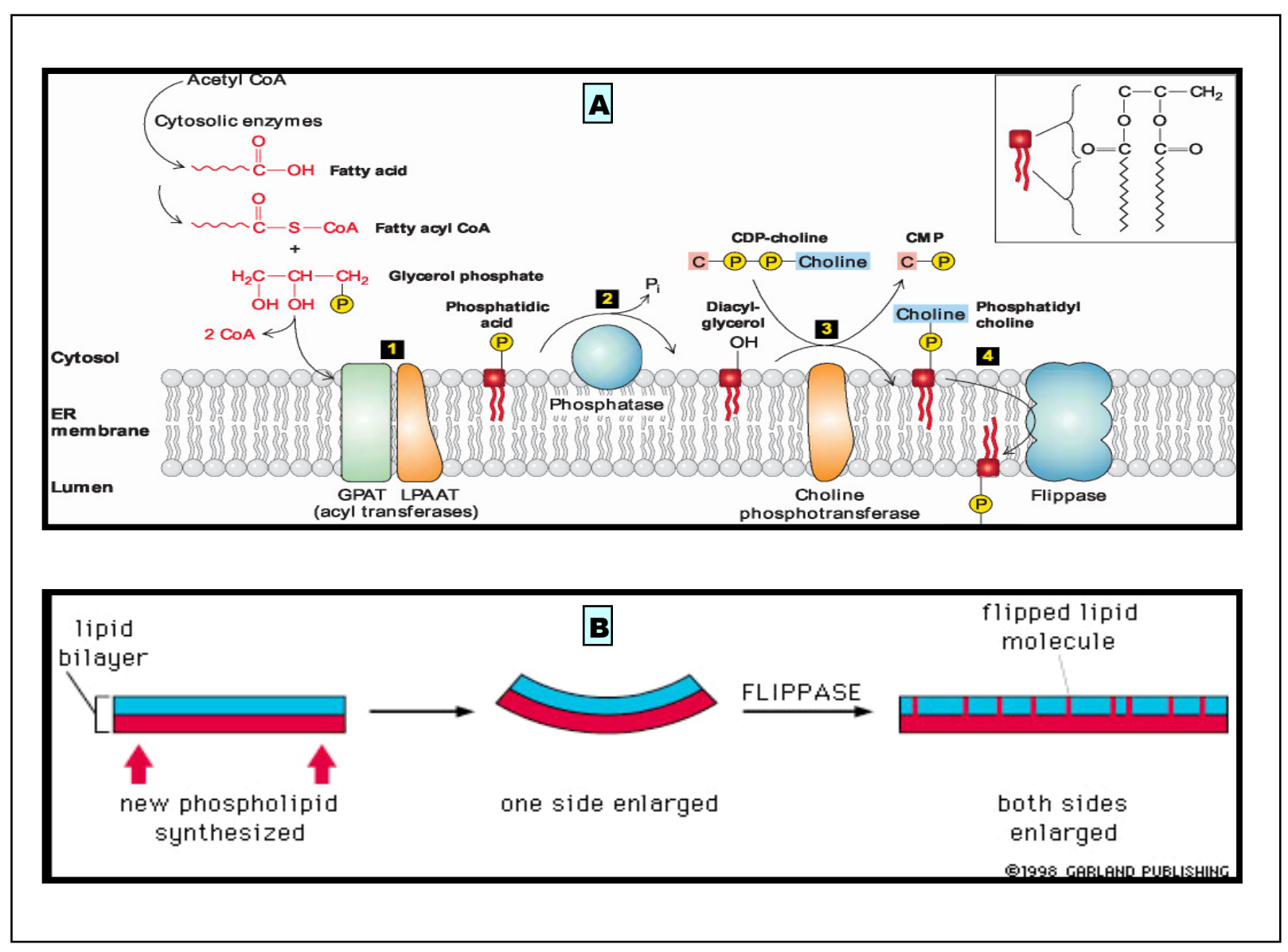

Gambar 13. Sintesis dan Pergerakan Fosfatidilkolin; A. Sintesis fosfatidilkolin (Lodish et al., 2002); B. Pergerakan fosfatidilkolin oleh enzim flipase (Lutsenko, 1998) 
Hasil penelitian yang dilakukan Curry dan Watson (1995) fosfolipid berfungsi sebagai pemeliharaan integritas membran dan permukaan yang dinamis antar sel serta sebagai pelindung terhadap lingkungannya (29). Lesitin juga berperan dalam mempertahankan dan melindungi integritas selubung spermatozoa $(16,28,29)$. Menurut Devlin (1993) lesitin mengandung gliserol, asam lemak, asam fosfat dan kolin, serta mempunyai fungsi membangun struktur dan proses metabolisme pada membran (30).

Analisis regresi linier pada hasil penelitian ini (Gambar 12) menunjukkan integritas membran yang baik akan memberikan pengaruh yang sangat nyata $(P<0,01)$ pada motilitas spermatrozoa. Hal ini sesuai juga dengan pendapat yang mengatakan adanya peningkatan integritas membran, akan meningkatkan integritas fungsional membran spermatozoa.

Peningkatan integritas fungsional membran spermatozoa akan meningkatkan penyerapan substrat untuk energi spermatozoa yang pada akhirnya akan meningkatkan motilitas spermatozoa $(31,32)$. Hal ini sesuai juga dengan penelitian Marlina, (1978) pada pemberian fosfolipid esensial terjadi peningkatan konsentrasi dan motilitas progresif spermatozoa (31).

Peningkatan motilitas ini disebabkan oleh pengaruh fosfolipid pada integritas membran dalam bentuk sebagai sumber energi, serta melindungi spermatozoa dari cold shock (34). Pemberian fosfolipid akan meningkatkan sintesis lipid membran pada retikulum endoplasma sehingga terjadi peningkatan struktur membran spermatozoa (6). Dengan adanya peningkatan struktur membran yang lebih banyak dari spermatozoa dan kerusakan membran yang minimal akan mengakibatkan jumlah membran spermatozoa yang baik akan meningkat sehingga hal ini menyebabkan persentase hidup spermatozoa meningkat (32).

Hal ini sesuai hasil yang diperoleh pada penelitian ini, dimana analisis regresi linier (Gambar 12) menunjukkan integritas membran yang baik memberikan pengaruh yang nyata $(P<0,05)$ pada viabilitas spermatozoa.

Sintesis membran lipid pada sel terjadi dalam retikulum endoplasma, sebagai prekursornya adalah fatty acyl COA (molekul ampifatik yang berada dalam membran retikulum andoplasmik), gliserol 3-fosfat dan cytidine diphospho-etanolamine (CDP-etanolamine) (dua molekul yang larut dalam air yang berada dalam sitosol). Biosintesis fosfatidilkolin sebagai berikut: Aktivasi asam lemak yang pertama oleh enzim sintesis asam lemak akan terbentuk Asil-CoA, selanjutnya akan mengalami aktivasi yang kedua sehingga terbentuk Asil-CoA. Asil-CoA dengan asam fosfatidat akan membentuk diasilgliserol dengan bantuan enzim fosfatase asam fosfatidat. Diasilgliserol dengan sitidin difosfokolin (CDP-kolin) akan membentuk fosfatidilkolin dengan bantuan enzim fosfotransferase diasilgliserolkolin. Sintesis membran fosfolipid ini sangat aktif pada daerah sitosol retikulum endoplasmik $(7,8,35,36,37)$.

Setelah terbentuk fosfolipid selanjutnya akan bergerak dari retikulum endoplasma ke membran sel ataupun ke membran organel sel yang lain. Mekanisme pergerakan ini ada dua teori yaitu: (1) membrane budding, vesikel membran retikulum endoplasma yang berisi fosfolipid menjulur ke luar membentuk tonjolan dan selanjutnya berfusi dengan membran organel yang lain, (2) phospholipid exchange protein, protein yang larut dalam air dapat mengikat fosfolipid dari satu membran (retikulum endoplasma) dan melepaskannya pada lain membran atau organel lain $(8,37,38,39)$. Teori yang kedua diperantarai oleh enzim flipase yang berfungsi memindahkan fosfolipid ke membran lain atau organel lain (Gambar 13).

Pemberian fosfolipid PC pada spermatozoa yang dilanjutkan dengan proses SGDP, sesuai hasil penelitian ini menunjukkan terjadi peningkatan kualitas spermatozoa pada semua variabel. Peningkatan kualitas spermatozoa ini, terjadi karena fosfolipid PC berperan dalam bentuk $(37,40,41,42,43)$ :

1. Fosfolipid PC akan masuk dalam sintesis membran lipid pada sel yang terjadi di dalam retikulum endoplasma, dengan terlebih dahulu kolin pada PC akan terlepas oleh peran enzim, dan diasilgliserol akan masuk dalam proses sintesis membran lipid.

2. Fosfolipid PC ketika berada pada permukaan sel, akan terjadi difusi ke dalam sel melalui peran enzim flipase yang akan berperan memindahkan ke sel yang membutuhkan fosfolipid PC.

Flipase banyak didistribusikan pada sebagian besar membran sel plasma. Aktifitas flipase telah berhasil dideteksi pada berbagai jenis sel dan membran yang meliputi limposit, hepatosit, spermatozoa, dan fibroblast. Enzim flipase berfungsi memindahkan fosfolipid ke membran lain atau organel lain (40).

\section{KESIMPULAN}

1. Pemberian fosfolipid PC pada spermatozoa sapi yang dilanjutkan dengan proses SGDP dapat meningkatkan integritas membran spermatozoa dan mempertahankan motilitas spermatozoa, viabilitas spermatozoa, spermatozoa belum kapasitasi, spermatozoa yang mengalami kapasitasi, dan spermatozoa yang mengalami reaksi akrosom.

2. Konsentrasi fosfolipid PC $10 \%$ merupakan konsentrasi yang terbaik/optimal dalam menghasilkan kualitas spermatozoa yang baik pada semua variable setelah proses SGDP. 


\section{SARAN}

1. Hasil penelitian ini perlu dilanjutkan dengan penelitian pembuahan infitro.

2. Perlu dilaksanakan penelitian tentang bagian membran mana yang mengalami kerusakan pada proses SGDP.
3. Untuk penelitian ke depan, perlu dipertimbangkan pemberian antioksidan untuk mengatasi kerusakan membrane pada proses SGDP yang disebabkan oleh peningkatan radikal bebas (pengaruh kimia).

\section{DAFTAR KEPUSTAKAAN}

1. Susilawati T. Fisiologi Spermatozoa: Kapasitasi, Reaksi Akrosom dan Fertilisasi. Malang: Penerbit Lembaga Penerbitan Fakultas Pertanian Universitas Brawijaya. 2002.

2. Tucker KE dan CAM Jansen. Sperm Separation Techniques: Comparison and Evaluation of Gradien Product. Proceedings 2 ${ }^{\text {nd }}$ International Workshop for Embryologists: Troubleshooting Activities in the ART Lab. 2002.

3. White GA dan B Darin. Lipid of Human Semen, In Human Semen and Fertility Regulation in Man. Edited by Hafes ESE. The CV Mosby Comp. St. Louis, dalam: Susilawati, Fisiologi Spermatozoa: Kapasitasi, Reaksi Akrosom dan Fertilisasi. Malang: Lembaga Penerbitan Fakultas Pertanian Universitas Brawijaya. 1976.

4. Hafez ESE dan MRN Prasad. Functional Aspect of The Epididimis. In (Hafez ESE,eds). Human Semen and Fertility Regulation in Men. St. Louis. The C.V. Mosby Comp. 1976; 31 - 40. Dalam: Susilawati, Fisiologi Spermatozoa: Kapasitasi, Reaksi Akrosom dan Fertilisasi. Malang: Lembaga Penerbitan Fakultas Pertanian Universitas Brawijaya.

5. Bowyer DE, PF Ang, dan Davies. Effect of EPL on the Metabolism of lipid in Arterial Wall, With Compliment of Phytophosphilids (PPL). 1979; 160-163.

6. Hegner D. Efect of Essential Phospholipids on the AT Pases and on the Fluidity of Liver Plasma Membrane. With compliments of Phytophospholipid (PPL). 1997; 87-95.

7. Evans G dan WMC Maxwell. Salomon's Artificial Insemination of Sheep and Goad. Butterworth. Sydney. 1987.

8. Darnell J, H Lodish, dan D Baltimore. Molecular Cell Biology, 2nd edition. Sci. Am. Books. 1990; 491 - 527.

9. Steel RGD dan JH Tornie. Principles and Procedures of Statistics: a Biometrical Approach. 2-nd edition. Mc Graw Hill. 1987.

10. De Garmo EP, WG Sullivan, dan CR Canada. Enginering Economy. $7^{\text {th }}$ Editing Mac. New York: Millan, Publ Co. 1984.

11. Hafez ESE dan B Hates. $X$ and Y Chromosome Bearing Spermatozoa, In Reproduction In Farm Animal. 7 edition. Lea and Febiger Philadelphia. 2000.

12. Djati MS. Peran Buffer $\mathrm{NaHCO}_{3}$ pada $\mathrm{BO}$ Medium pada Dalam Menginduksi Kapasitasi, Reaksi Akrosom, Viabilitas Sperma, dan Penetrasi Sperma Terhadap Oosit pada Fertilisasi Invitro Sapi. Jurnal IImu-IImu Hayati, 2005; 6 (1).

13. Correa JR, GHeersche Jr dan PM Zavos. Sperm Membrane Functional Integrity and Response of Frozen-Thawed Bovine Spermatozoa during Hypoosmotic Swelling Test Incubation at Verying Tempoetarures. Theriogenology. 1997; 47:715-721.

14. Hirai M, WA Cerbito, MPB Wijayagunawardane, J Braun, W Leidl, K Ohosaki, T Matsuzawa, K Miyazawa dan K Sato.. The Effect of Viscosity of Semen Diluents on Motility of Bull Spermatozoa. Theriogenology 47. Elsevier Science Inc. 1997; 1463-1478.

15. Garner DL dan ESE Hafez. Spermatozoa and Seminal Plasma In Reproduction in Farm Animal. 7-th edition. Edited by Hafez B, Hafez ESE. Lea and Febiger. Philadelphia, 2000; 96-109.

16. Berden HJ and JW Fuquay. Applied Animal Reproduction. 2-nd edition. Virginia: Res Pub. Co, Inc. Prentice Hall. Reston. 1984.

17. Zenichiro K, Herliantien. Sarastina. Tecnology of Frozen Semen Processing Fro Cattle (Manual Introduction). Malang: Balai Inseminasi Buatan Singosari. 2002.

18. Ax RL, M Dally, BA Didion, RW Lenz, CC Love, DD Varner, B Hafez, dan ME Bellin. 2000. Semen evaluation. In: Reproduction In Farm Animals. Philadelphia: Lea and fegiber. 2000; 365-375.

19. Check JH, D Katsoff, J Rozak, dan D Lurie. Effeck of swim up, percoll and sephadex sperm separation methods on the hypoosmotic swelling test. Human Reprod, 1992; 7.1:109-111.

20. Susilawati T, SB Sumitro, HP Soehartojo, Y Mantra, dan Nuryadi. Pola Kapasitasi Spermatozoa X dan Y Sapi Hasil Pemisahan Menggunakan Filtrasi Sephadex dan Sentrifugasi Gradien Densitas Percoll. Jumal Penelitian Ilmu-Ilmu Hayati (Life Sciences) Lembaga Penelitian Unibraw. Juni 1999; 11(1): 29-40.

21. Hafez ESE. Reproduktion in Farm Animal 6 th Edition. Lea and Febiger. Philadelphia. 1993;440-443.

22. Nainar MA, BM Easwaran, dan V Ulngathan. Studies on No-Motile Spermatozoa (static semen) in Buffalo Bull Semen. Indian Vet.J. 1991; 67:133-135.

23. Alvarez JG, JC Touchstone, L Blasco, dan BT Storey. Spontaneus lipid preoxidation and Production Hydrogen Peroxide 
and Superoxide in Human Spermatozoa-Superoxide dismutase as Major Enzyme Protectant Against Oxygen Toxiciti. J. Androl, 1987; 8: 336-348.

24. Yanagimachi R. Mammalia Fertilization. In: Knobil E, Neill JD. The Physiology of Reproduction. New York: Raven Press, Ltd. 1988; 5: 138-152.

25. Buhr MM. Manipulation of sperm to improve fertility in new direction in animal production system. Proceeding of the annual meeting Canadian society of animal scince July 5-8 1008. Vancouver, British Columbia Canada VGT 124. Ed by Blair R Raja, R Mahendra, M Mohan, LS Stephen, Yang My. 1998; 334-336.

26. Thanphaichitr N, YS Zheng, M Kates, N Abdullah, dan A Chan. Cholestrol and Phophoslipid Levels of Washed and Percoll Gradien Centrifuged Mouse Sperm. Presence of lipids Possessing inhibitory effects on sperm motility. Mol. Reprod Dev, 1996; 43: 187-195.

27. Gusman EG, M Ollero, MC Lopez, RK Sharma, JG Alvarez, AJ Thomas, dan A Agarwal. Differential production of Reactive Oxygen Species by Subsets of Human Spermatozoa at different Stages of Maturation. Hum. Reprod, 2001; 16(9): 1922-1930.

28. Hammadeh ME, T George, P Rosenbaum dan W Scmidt. Association Between Freezing Agent and Acrosom Damaged of Human Spermatozoa from Subnomal and Normal Semen. Andrologia. 2001; 33: 331-336.

29. Cury MR dan PF Watson. Sperm Structure and Fungtion. In Gametes-The Spermatozooa. Edited by. Grudzinskas JG and JL Yovich. Cambridge: Cambridge University Press. 1995; 45 - 67

30. Devlin TM. Text Books of Biochemistry. A John Willey and Songs. New York.: Inc. Publications. 1993.

31. Mitchel JA, L Nelson, dan ESE Hafes. Motility of spermatozoa. In (Hafez ESE, eds). Human semen and fertility regulation in men. St. Louis, The C.V. Mosby Comp. 1976; 83 - 97.

32. Hafez ESE. The semen. In (Hafez ESE, eds) Human reproduction, Conception and Contraception. $2^{\text {nd }}$ edition. Hegerstown, Haeper \& Row. 1980; 99-103.

33. Marlina A, Onny, Amitaba IGB, dan A Adimoelja. Pengobatan Pria Subfertil dengan Androgen dan fosfolipid Esencial. Proceding Symposium Spermatologi. Surabaya: Fakultas Kedokteran Universitas Airlangga . 1978; 301-305

34. Evans WH, dan JM Graham. Membrane structure and function. IRL Press. Oxford University Press. Ox-ford. 1989; 11-28.

35. Dowhan W. Molecular basis for membrane phospholipids diversity: why are there so many lipids? Ann. Rev. Biochem. 1997; 66:199-232.

36. McMaster CR dan RM Bell. Phosphatidylcholine Biosynthesis via the CDP-choline Pathway in Saccharomyces cerevisiae. The Journal Of Biolwicaclh Emistry, Issue of May 20, 1994; 269(20):14776-14783.

37. Lodish, Berk, Matsudaira, Kaiser, Kreiger, Scott, Zipursky, Darnell. Moleculer Cell Biology. 2002; 743-750.

38. Daleke DL dan JV Lyles. Identification and purification of aminophospholipid flippases. Biochim. Biophys. Acta. 2000; 1486:108-127.

39. Henneberry AL, MM Wright, dan CR McMaster. The major sites of cellular hospholipid synthesis and molecular determinants of fatty acid and lipid head group specificity. Mol. Biol. Cell, 2002; 13: 3148-3161.

40. Pomorski T dan AK Menon. Lipid Flippases and their biological functions. Cell. Mol. Life Sci, 2006; 63: 2908-2921.

41. Chang QI, SN Gummadi, dan AK Menon. Chemical Modification Identifies Two populations of Glycerophospholipid Flippase in Rat Liver ER. American Chemical Society Published on Web. 2004; 43: 10710-10718.

42. Graham TR. Flippases and Vesicle-mediated Protein Transport. Trends in Cell Biology. 2004; 14(12).

43. Lutsenko S. Membrane Proteins and Lipids Membrane Structure. Dept. Biochemistry and Mol. Bology MRB 624, Ext. 46953, lutsenko@ohsu.edu. Garland Publishing. 1998. 

